DOI: 10.17117/na.2016.01.02.447

http://ucom.ru/doc/na.2016.01.02.447.pdf

Поступила (Received): 26.01.2016

\author{
Халиков И.С. \\ Содержание ПАУ в донных отложениях \\ озера Байкал в районе Селенгинского \\ мелководья
}

\author{
Khalikov I.S. \\ The contents of PAHs in bottom sediments of the Baikal \\ lake in the region of the Selenga shallow waters
}

В сообщении представлены результаты мониторинга (2011,2013-2015 г2.) бенз(а)пирена и других ПАУ в донных отложениях авандельты $p$. Селенга с использованием метода ВЭЖХ и флуориметрического детектора. Наибольшие уровни полиаренов были найдены в пробах речных выносов протоки Усть-Харауз. Антропогенное загрязнение ПАУ донных отложений Селенгинского мелководья незначительно и мало выделяется на фоне природных процессов

Ключевые слова: Байкал, Селенга, донные отложения, ПАУ, ВЭЖХ

\section{Халиков Ильдус Салихович}

Кандидат химических наук, ведущий научный сотрудник

Научно-производственное объединение "Тайфун» 2. Обнинск, ул. Победы, 4

\begin{abstract}
The results of benzo(a)pyrene and other PAHs monitoring in bottom sediments of the Selenga river avant-delta obtained in 2011, 2013, 2014 and 2015 obtained with the use of the HPLC method and the fluorimetric detector are presented. The highest levels of polyarenes were found in the samples of the Ust-Harauz river channel washouts. The anthropogenic contamination with PAHs of the Selenga shallow waters bottom sediments was insignificant and was slightly distinguished against the background of natural processes

Key words: Baikal, Selenga, bottom sediments, PAH, HPLC
\end{abstract}

\section{Khalikov Ildus Salikhovich}

Candidate of Chemical Sciences, Leading Researcher Research and production association "Typhoon" Obninsk, Pobedy st.,4

Озеро Байкал, является самым глубоким (1637 м) и крупным (более 23000 км $^{3}$ ) пресноводным водоёмом Земли, оно содержит около $20 \%$ от объёма всех мировых запасов поверхностных пресных вод. Для сохранения биоразнообразия оз. Байкала необходимо знать современный уровень загрязнения озера вредными веществами.

В озеро впадает более 300 рек и свыше половины притока даёт р. Селенга, которая может представлять потенциальную опасность в качестве источника загрязнения оз. Байкал. На территории водосбора р. Селенги в России имеются следующие промышленные узлы - Нижнеселенгинский, Улан-Удэнский и Гусиноозерский.

Донные отложения (ДО) являются депонирующей средой, отражающей в отличие от воды не текущее, а накопленное за длительный период загрязнение. 
ДО традиционно используются в качестве индикатора для выявления интенсивности антропогенного загрязнения. Наблюдения за загрязнением ДО являются неотъемлемой частью мониторинга состояния водных объектов.

В водном стоке р. Селенга в озеро постоянно обнаруживаются высокие концентрации нефтяных углеводородов. На авандельте р. Селенга может аккумулироваться в донных отложениях большая часть речной взвеси с загрязняющими веществами, включая и полициклические ароматические углеводороды (ПАУ). Загрязнение донных отложений ПАУ может привести к ухудшению качества воды (через вторичное загрязнение), угнетению и гибели биоты и деградации водной экосистемы. В данном сообщении представлены результаты определения содержания ПАУ в донных отложениях прибрежной части оз. Байкал (авандельты р. Селенга) в 2011, 2013-2015 гг.

Материалы и методы исследования. Материалом для исследований послужили 47 проб ДО, отобранных в 2011-2015 гг. с помощью дночерпателя «Океан», в пределах глубин отбора от 10 до 50 метров (рис.1), во время экспедиционных работ, проводимых ФГБУ «ГХИ» (г. Ростов-на-Дону) в летнее время. Основной полигон наблюдений на Селенгинском мелководье протянулся от протоки Прорва на западном участке до мыса Хребтовский на востоке [1]. Пробы До были отобраны с ненарушенного поверхностного слоя осадков (0-2 см), высушены при температуре не более 40 ㄷ $и$ измельчены в ступе до гомогенного порошка.

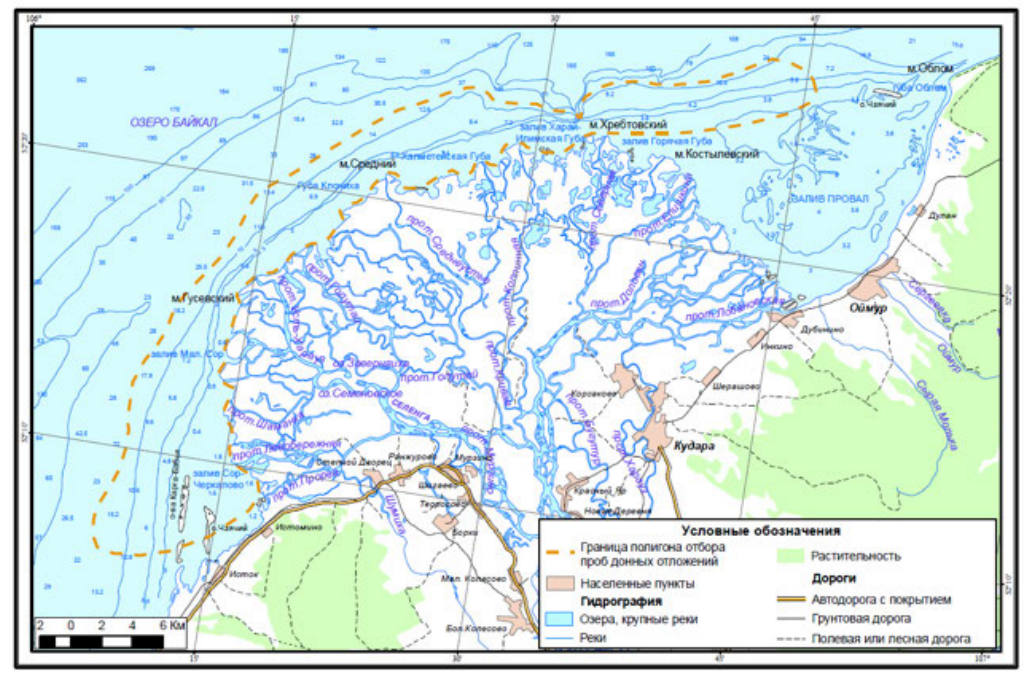

Pис. 1. Схема отбора проб в авандельте р. Селенга [1]

Метод анализа был основан на выделении ПАУ из 2 г донных отложений экстракцией гексаном (10 см³ х 2) под действием ультразвука в течение 10 мин, фильтровании через бумажный фильтр, концентрировании объединенных экстрактов на ротационном испарителе в вакууме водоструйного насоса или в токе азота при температуре не выше $40^{\circ} \mathrm{C}$ до объёма 1-2 $\mathrm{cm}^{3}$, очистке полученного экстракта от мешающих примесей с помощью твердофазной экстракции и использования вакуумного манифолда VacMaster-10 на картриджах с силикагелем (1г/6мл, 63-200 мкм, Selecto Scientific), элюировании ПАУ ацетонитрилом и разделении компонентов методом ВЭЖХ. Процент извлечения ПАУ (от флуорена до коронена) составлял примерно 70\%. 
Для идентификации и количественного определения ПАУ использовали метод ВЭЖХ с флуориметрическим детектированием (детектор «RF-20A»). Измерения проводили на хроматографе «LC-20 Prominence» (Shimadzu) с колонкой Envirosep PP (125 x 3,2 мм, 5 мкм) и защитным картриджем C18 (4 х 2 мм) производства фирмы Phenomenex в условиях градиентного элюирования смесью ацетонитрила и воды от $70 \%$ до 90\%, при скорости потока 0,75 мл/мин и температуре колонки $40^{\circ} \mathrm{C}$. Объем ввода аликвоты - 10 мкл. С помощью программного обеспечения «LC Solution» устанавливали оптимальные длины волн возбуждения и эмиссии. В качестве градуировочных стандартов использовали стандартные растворы индивидуальных ПАУ и их смесей производства фирмы «Supelco» и «Dr. Ehrenstorfer GmbH». Правильность результатов определения ПАУ подтверждали методом «введено - найдено».

Интервал определения массовой концентрации ПАУ в донных отложениях составлял от 0,05 до 100 мкг /кг для разных соединений. Методика обеспечивала выполнение измерений с погрешностью, не превышающей 30\%, при доверительной вероятности 0,95. Суммарная концентрация ПАУ в работе представлена как сумма 16 полиаренов (от 3 до 7 конденсированных колец).

Органический углерод в ДО определяли методом сухого сжигания, и гранулометрический анализ выполняли методом лазерной дифракции $[3,4]$.

Результаты и обсуждение. В пробах ДО в настоящей работе были количественно определены в порядке выхода на хроматограммах следующие индивидуальные ПАУ - флуорен, фенантрен, антрацен, флуорантен, пирен, бенз(a)антрацен, хризен, бенз(е)пирен, бенз(b)флуорантен, бенз(k)флуорантен, бенз(a)пирен, дибенз(a,h)антрацен, бенз(g,h,i)перилен, инден[1,2,3-c,d]пирен, антантрен и коронен (рис.2). Исследование особенностей профиля среднего содержания ПАУ в 2011-2015 гг. показало, что значения варьируют в определенных пределах, оставаясь примерно на одном уровне.

По результатам обследования 2011, 2013-2015 гг., распределение бенз(а)пирена и ПАУ в ДО авандельты р. Селенга показало неоднородный характер. Результаты по средней концентрации бенз(а)пирена и суммы 16 ПАУ, а также интервалы их значений в донных отложениях обследуемого района приведены в таблице 1 .

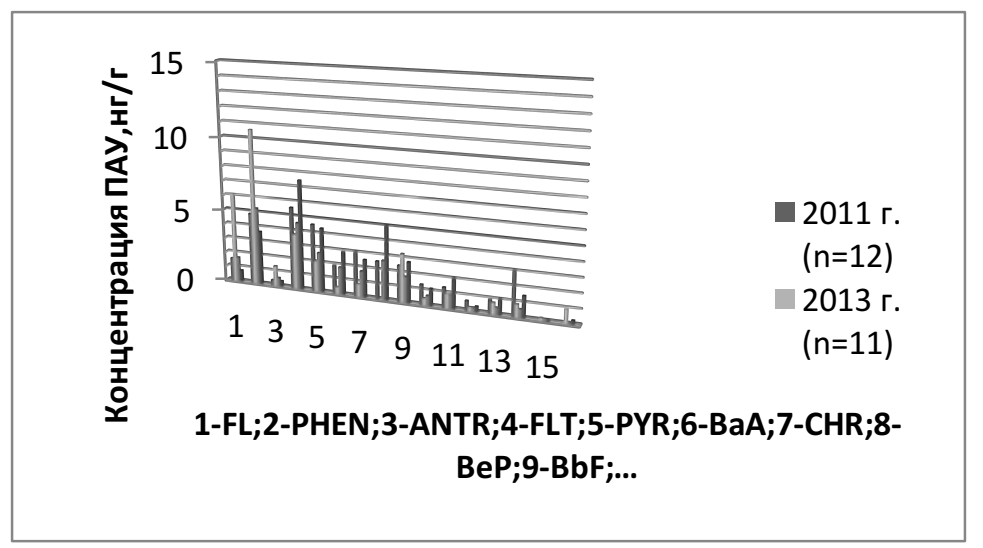

Pис. 2. Профиль среднего содержания ПАУ в донных отложениях авандельты р. Селенга в 2011-2015 г2. 
Содержание бенз(а)пирена в донных отложениях авандельты р. Селенга изменялось в разные годы от 0,05 до 7,9 нг/г, а сумма ПАУ варьировала от 3,0 до 150 нг/г сухого веса. Максимальные концентрации БаП (7,9 нг/г) и суммы 16 ПАУ (150,0 нг/г) были обнаружены в пробах алевритовых илов речных выносов протоки Усть-Харауз. Наиболее загрязненным районом донных отложений Селенгинского мелководья является юго-западный участок от мыса Средний до протоки Шаманка.

Таблица 1. Среднее содержание бенз(а)пирена и суммы 16 ПАУ в донных отложениях авандельты р. Селенга, нг/г (2011, 2013-2015 г2.)

\begin{tabular}{|l|c|c|c|c|}
\hline \multicolumn{1}{|c|}{ Концентрация ПАУ } & $\begin{array}{c}2011 \text { г. } \\
(\mathrm{n}=12)\end{array}$ & $\begin{array}{c}2013 \text { г. } \\
(\mathrm{n}=11)\end{array}$ & $\begin{array}{c}2014 \Gamma . \\
(\mathrm{n}=12)\end{array}$ & $\begin{array}{c}2015 \text { г. } \\
(\mathrm{n}=12)\end{array}$ \\
\hline $\begin{array}{l}\text { Средняя концентрация БаП, } \\
\text { интервал, нг/г }\end{array}$ & $\begin{array}{c}1,4 \\
(0,05-7,8)\end{array}$ & $\begin{array}{c}1,0 \\
(0,2-1,7)\end{array}$ & $\begin{array}{c}1,0 \\
(0,1-3,1)\end{array}$ & $\begin{array}{c}2,1 \\
(0,1-7,9)\end{array}$ \\
\hline $\begin{array}{l}\text { Средняя концентрация 16 } \\
\text { ПАУ, интервал, нг/г }\end{array}$ & $\begin{array}{c}34,8 \\
(6,8-112,6)\end{array}$ & $\begin{array}{c}33,5 \\
(17,7-61,5)\end{array}$ & $\begin{array}{c}26,3 \\
(4,9-150,0)\end{array}$ & $\begin{array}{c}36,9 \\
(3,0-125,0)\end{array}$ \\
\hline
\end{tabular}

Концентрации ПАУ в донных отложениях обусловлены сорбционными свойствами осадков, наиболее высокое содержание отмечалось в мелкодисперсных ДО, обладающих большей активной площадью поверхности. Выявлены прямые корреляционные зависимости между содержанием ПАУ, органического углерода и гранулометрического состава $[3,4]$. Органическое вещество играет значимую роль в аккумуляции в донных отложениях ПАУ.

Оценка загрязненности приоритетными ПАУ донных отложений районов авандельты р. Селенга проводилась по шведской классификации загрязненности донных отложений [2]. Согласно этой классификации, значительная часть проб Д0, отобранных в авандельте р. Селенга, относится к классу №2 с «низкими» концентрациями ПАУ. К 3-му классу с «умеренными» концентрациями ПАУ относятся несколько проб авандельты р. Селенга, в основном на траверсе протоки Усть-Харауз, из 47 отобранных. Основной вклад в загрязнение До по данной системе вносят низкомолекулярные ПАУ - фенантрен, флуорантен, пирен, бенз(а)антрацен, хризен.

Выводы и рекомендации: Уровни загрязнения донных отложений района Селенгинского мелководья оз. Байкал относительно невысоки и указывают на незначительную антропогенную нагрузку со стороны крупнейшего притока p. Селенга в качестве источника загрязнения. Рекомендуется расширить границы полигона и производить отбор проб на глубинах более 50 метров, на которых могут наблюдаться максимальные концентрации загрязняющих веществ. Необходим отбор ДО по глубине осадков для изучения распределения ПАУ в этом районе в прошлые годы.

\section{Список используемых источников:}

1. Государственный доклад «О состоянии озера Байкал и мерах по его охране в 2013 году». М, 2014. $462 c$.

2. ICES. 2003. Report of the ICES Advisory Committee on the Marine Environment, 2003. ICES Cooperative Research Report, 263. Annex 3: Inventory of sediment quality criteria in ICES member countries. 227 pp. 
3. Халиков И.С., Левшин Д.Г., Макаренко А.А. О влиянии гранулометрического состава на распределение органического углерода в донных отложениях озера Байкал // Современное общество, образование и наука. Тамбов. 2015. С. 160-161.

4. Халиков И.С., Левшин Д.Г. Корреляционная зависимость концентрации ПАУ и органического углерода в донных отложениях озера Байкал // Современное общество, образование и наука. Тамбов. 2015. C. 161-162.

(C) 2016, Халиков И.С.

Содержание ПАУ в донных отложениях озера

Байкал в районе Селенгинского мелководья
(C) 2016, Khalikov I.S.

The contents of PAHs in bottom sediments of the Baikal lake in the region of the Selenga shallow waters 